A GUIDE TO UK MONETARY POLICY 


\title{
A GUIDE TO UK MONETARY POLICY
}

\author{
by \\ PAUL TEMPERTON
}

Palgrave Macmillan 
ISBN 978-1-349-07998-8 ISBN 978-1-349-07996-4 (eBook)

DOI 10.1007/978-1-349-07996-4

(C) Paul Temperton, 1986

Softcover reprint of the hardcover 1st edition 1986

All rights reserved. For information, write:

Scholarly \& Reference Division,

St. Martin's Press, Inc., 175 Fifth Avenue, New York, NY 10010

First published in the United States of America in 1986

ISBN 978-0-312-35306-3

Library of Congress Cataloging-in-Publication Data

Temperton, Paul, 1958-

A guide to UK monetary policy.

Includes index.

1. Monetary policy-Great Britain. 2. Interest

rates-Great Britain. 3. Money market-Great Britain.

I. Title.

HG939.5.T45 1986

$332.4^{\prime} 941$

$85-27867$

ISBN 978-0-312-35306-3 
To Nicky 


\section{Contents}

Chapter

Page

List of Tables $\quad$ ix

List of Figures $\quad x i$

Preface xiii

List of Abbreviations $\quad$ xv

Glossary of Terms xvii

1. Background to the Introduction of Monetary Targets in the UK

2. Monetary Targets in the UK 7

(i) the introduction of monetary targets 7

(ii) the development of the Medium Term Financial Strategy 9

(iii) measures of money in the UK 18

(iv) the calculation of monetary targets 25

3. Analysing Broad Money 29

(i) consolidated balance sheet of the UK monetary sector 30

(ii) financing the PSBR 38

(iii) the counterparts to $\mathrm{EM} 3$

(iv) the domestic counterparts 45

(v) the external counterparts 53

(vi) net non-deposit liabilities $\quad 59$

(vii) seasonal adjustment of $\mathrm{fM} \quad 60$

(viii) counterparts to other measures of broad money 62

4. Analysing Narrow Money 64

(i) $\mathrm{MO}$ as a measure of transactions balances 66

(ii) $\mathrm{MO}$ and inflation 68

(iii) explaining the behaviour of $\mathrm{MO}$

(iv) controlling MO 
5. Setting Short Term Interest Rates: the Policy Process 80

(i) the influence of the monetary aggregates 80

(ii) the exchange rate $\quad 83$

(iii) other influences $\quad 85$

6. Setting Short Term Interest Rates in the Money Market 89

(i) 'administered' versus 'market related' interest rates $\quad 89$

(ii) the role of the Bank of England in the money market 91

(iii) the objective of money market operations 93

(iv) techniques for relieving money market shortages 93

(v) techniques for absorbing a money market surplus $\quad 95$

(vi) recent experience with setting short term interest rates 96

$\begin{array}{ll}\text { (vii) the interbank market } & 97\end{array}$

7. Funding the PSBR and Monetary Growth 101

(i) types of government debt 102

(ii) National Savings $\quad 104$

(iii) Certificates of Tax Deposit 106

(iv) Treasury bills 106

(v) Gilt edged stocks $\quad 107$

$\begin{array}{ll}\text { Appendix: Types of National Savings } & 110\end{array}$

$8 \quad$ The Gilt Edged Market 113

(i) the institutional structure of the gilt market 113

(ii) methods of selling gilts 117

(iii) explaining the shape of the yield curve 119

Appendix: Models of Gilt Yields $\quad 129$

$\begin{array}{lll}\text { 9. } & \text { Conclusion } & 138\end{array}$

(i) the distinction between broad and narrow money 138

(ii) why the counterparts approach to $E M 3$ ? 139

(iii) problems with $\mathrm{EM} 3 \quad 140$

(iv) banks and building societies $\quad 141$

(v) the demise of liability management 141

(vi) the usefulness of the quantity theory of money 142

(vii) money GDP as an alternative 143

(viii) money as a leading indicator of inflation 144

(ix) the exchange rate as a monetary indicator 144

Appendix 1: Official Interest Rates, 1932 to 1985

Appendix 2: Monetary Policy Measures, 1970 to 1985150

Index 


\section{List of Tables}

1.1 Inflation trends, 1958-1981 3

2.1 Monetary targets set in the UK and results achieved 8

2.2 The MTFS and monetary growth 11

2.3 The MTFS and the PSBR/GDP ratio 11

2.4 Monetary aggregates: stocks, mid-April $1985 \quad 19$

2.5 Construction of target period growth rates for $\mathrm{fM} 327$

3.1 Consolidation of two banks' balance sheets 32

3.2 Influence of transit items; day 1

3.3 Influence of transit items; day 2

3.4 Consolidated balance sheet allowing for transit items 33

3.5 Balance sheet with foreign currency business; month $1 \quad 35$

3.6 Balance sheet with foreign currency business; month $2 \quad 35$

3.7 Balance sheet with foreign currency business, including

3.8 Balance sheet with foreign currency business, including revaluations 37

3.9 Consolidated balance sheet of the UK monetary sector 38

3.10 Public sector borrowing requirement and other counterparts to changes in money stock 44

3.11 fM3 and overfunding, 1977/78 to 1984/85 51

3.12 Relationship between external and foreign currency

3.13 Examples of the influence of overseas purchases of gilts on $\mathrm{EM} 3$

7.1 Composition of the National Debt 103

7.2 Purchases of central government debt by the non-bank private sector 104

$\begin{array}{ll}\text { 7.3 National Savings targets and results achieved } & 105\end{array}$

$\begin{array}{ll}\text { 8.1 Money market returns } & 120\end{array}$

8.2 Maturity composition of gross official sales of gilts 129 


\section{List of Figures}

1.1 Ratio of government expenditure to GDP, 1955 to 1985

1.2 Broad money and inflation, 1971 to 1985

2.1 Recorded $\mathrm{fM} 3$ and the targets, April 1977 to April $1985 \quad 12$

2.2 Velocity of $f M 3 \quad 14$

2.3 Relationships among the narrow monetary aggregates and their components 20

2.4 Relationships among the broad monetary and liquidity aggregates and their components 21

3.1 Profitability of bill round-tripping, Jan-March 1985

4.1 MO and inflation, 1976 to $1985 \quad 69$

4.2 MO and inflation, 1961 to 1985

6.1 LCB base rates and the three month interbank rate 99

8.1 Institutional structure of the gilt market 114

8.2 Institutions in the new structure of the gilt

8.3 Low, medium and high coupon yield curves 122

8.4 Yield curves 123

8.5 Long/short interest rate ratio, 1976 to $1985 \quad 125$

8.6 Volatility against term 127

8.7 Yield curves, October 1981 and October 1984

8.8 Funding policy and relative yields 131 


\section{Preface}

The book was started in the Autumn of 1984 and finished a year later. Its central aim is to explain the way in which the UK authorities analyse monetary developments and implement monetary policy in the mid 1980s. The background to the introduction of monetary targets in the UK is discussed briefly in Chapter 1 . The second chapter follows on with a discussion of the development of policy since the introduction of announced quantitative targets for monetary aggregates: in particular, the development of the Medium Term Financial Strategy is examined. Chapters 3 and 4 concentrate on the analysis of broad and narrow money, respectively. Chapter 3 is based on a paper produced by the author for Hoare Govett in 1984; that paper was, in turn, a revised version of a Hoare Govett paper written by Tony Hotson in 1980. As well as the behaviour of the targetted monetary aggregates, various other indicators are examined by the UK monetary authorities (defined as the Bank of England, the Treasury and the Ministers responsible for economic policy) when coming to a judgement about the stance of policy. In particular, the behaviour of the exchange rate has been a most influential factor during the 1980s. Chapter 5 attempts to explain the various factors which are taken into account by the authorities, when coming to a decision about the stance of policy and the appropriate level of short term interest rates. Short term control of broad money in the UK has come to rely to a large extent on the authorities' funding behaviour and this is discussed in Chapters 7 and 8.

While the aim of the book is to provide a guide to the way in which the authorities analyse monetary developments and conduct monetary policy it must be recognised that there exists a wide diversity of opinion on such matters. The final chapter, therefore, attempts to draw attention to some of the more important continuing questions surrounding monetary policy in the UK: it may be read on its own as a general overview.

A large number of people have helped with the production of the book. Hoare Govett provided many of the facilities used in its production, in par- 
ticular those for typesetting and the drawing of charts. Theresa Willson carried out the typesetting with efficiency and speed and was thus of central importance in the book's production. Samantha Lear prepared the charts. Many people commented on the draft version of the book: Barry Johnston, Tony Hotson, David Porter and David Willetts should be singled out for special thanks in this respect. I remain, of course, responsible for any errors which remain.

Paul Temperton

October 1985. 


\section{List of Abbreviations}

(publications are shown in italic)

\begin{tabular}{|c|c|}
\hline $\begin{array}{l}\text { Bank } \\
\text { BB }\end{array}$ & $\begin{array}{l}\text { Bank of England } \\
\text { Bankers' operational balances held with the Bank of } \\
\text { England }\end{array}$ \\
\hline$B E Q B$ & Bank of England Quarterly Bulletin \\
\hline CCC & Competition and Credit Control \\
\hline CD & Certificate of Deposit \\
\hline CG & Central Government \\
\hline CGBR & Central Government Borrowing Requirement \\
\hline CGD & $\begin{array}{l}\text { Sales of central government debt to the banks, non-bank } \\
\text { private sector and overseas net of Bank of England pur- } \\
\text { chases of bills }\end{array}$ \\
\hline CRD & Cash ratio deposits held by banks at the Bank of England \\
\hline DCE & Domestic Credit Expansion \\
\hline EEA & Exchange Equalisation Account \\
\hline ELs & Eligible liabilities \\
\hline FS & Financial Statistics, published monthly by HMSO \\
\hline FSBR & $\begin{array}{l}\text { Financial Statement and Budget Report, otherwise known } \\
\text { as the 'Red Book', which is published each year on the } \\
\text { day of the Budget }\end{array}$ \\
\hline HMT & Her Majesty's Treasury \\
\hline IBELS & Interest Bearing Eligible Liabilities \\
\hline IDCB & Issue Department holdings of commercial bills \\
\hline IMF & International Monetary Fund \\
\hline LAs & Local Authorities \\
\hline LABR & Local Authorities' Borrowing Requirement \\
\hline LCB & London Clearing Bank \\
\hline LDMA & London Discount Market Association \\
\hline LDT & Licensed deposit-taker \\
\hline LIBOR & London Interbank Offered Rate \\
\hline MLR & Minimum Lending Rate \\
\hline MTFS & Medium Term Financial Strategy \\
\hline NAC & $\begin{array}{l}\text { Notes and coin held by both the bank and non-bank pri- } \\
\text { vate sectors }\end{array}$ \\
\hline
\end{tabular}


NNDL Net Non-Deposit Liabilities

NNDL\$ Foreign currency NNDL

NNDLf Sterling NNDL

NSB National Savings Bank

OF\$ Official foreign currency borrowing

OPS Other public sector

OSfD Overseas sector deposits in sterling with UK monetary sector

OS\$D Overseas sector deposits in foreign currencies with UK monetary sector

OSfL Lending by UK monetary sector in sterling to overseas sector

OS\$L Lending by UK monetary sector in foreign currencies to overseas sector

OSfG Sales of UK public sector debt to overseas sector

PCs Public Corporations

PCBR Public Corporations' borrowing requirement

PRVfD UK private sector deposits in sterling with UK monetary sector

PRVSD UK private sector deposits in foreign currencies with UK monetary sector

PRVfL Lending by UK monetary sector in sterling to UK private sector

PRVSL Lending by UK monetary sector in foreign currencies to UK private sector

PRVEG Sales of public sector debt to UK non-bank private sector

PRVNAC UK non-bank private sector holdings of notes and coin

PSBR Public Sector Borrowing Requirement

PUBED UK public sector deposits in sterling with UK monetary sector

PUBfL Lending by UK monetary sector in sterling to public sector

PUBSD UK public sector deposits in foreign currencies with UK monetary sector

PUB\$L Lending by UK monetary sector in foreign currencies to public sector

REPO Sale and repurchase agreement

RES International Reserves in the EEA

RPI UK Retail Prices Index

SCB Scottish Clearing Bank

SSD Supplementary Special Deposits 


\section{Glossary of Terms}

Accepting House: Traditionally accepting houses specialised in accepting (or guaranteeing) bills; they now have a wider banking role. There are sixteen accepting houses in London represented on the Accepting Houses Committee. The members are N.M. Rothschild \& Sons Ltd.; Baring Bros. \& Co. Ltd.; Brown Shipley \& Co. Ltd.; Charterhouse Japhet plc.; Robert Fleming \& Co. Ltd.; Guinness Mahon \& Co. Ltd.; Hambros Bank Ltd.; Hill Samuel \& Co. Ltd.; Kleinwort Benson Ltd.; Lazard Bros. \& Co. Ltd.; Samuel Montagu \& Co. Ltd.; Morgan Grenfell \& Co. Ltd.; Rea Bros plc.; J. Henry Schroder Wagg \& Co. Ltd.; Singer \& Friedlander Ltd.; and S.G. Warburg \& Co. Ltd.

Asset Management: The process whereby banks adjust the volume of their loans to equal the supply of deposits (the opposite process is termed liability management).

Bank Return: A weekly return from the Bank (released at 3 p.m. each Thursday) giving the balance sheets of the Bank's Issue and Banking Departments.

Banking Month: Defined as the period between monthly make-up days.

Banking Sector: The banking sector was replaced by the monetary sector at the end of 1981. It comprised those institutions included on the statistical lists of banks and discount market institutions, together with the Banking Department of the Bank of England. Inclusion on the statistical lists was based on informal appraisal of a bank's size and reputation and was usually closely linked with the granting of authorised bank status for exchange control purposes.

Banking Statistics: A monthly press release from the Bank giving new and revised data on some of the tables in the $B E Q B$.

Base Drift: If a new monetary target has a base level which is higher than the mid point of the previous target, base drift is said to occur. 
Bill Arbitrage: Alternatively referred to as bill round tripping, see below. Hard arbitrage refers to the practice of borrowing on bills in order to place the funds on deposit (at the same maturity) at a profitable margin. Such arbitrage inflates both bank lending to the private sector and EM3. Soft arbitrage involves switching to bill finance from other forms of finance (e.g. a base rate related overdraft); it does not inflate bank lending and EM3.

Bill Leak: The level of bills held by the non-bank private sector.

Bill Mountain: The portfolio of commercial bills held by the Bank of England. As the amount of intervention by the Bank in the money market has increased in recent years, the quantity of bills held by the Bank has increased substantially, standing at around $£ 15 \mathrm{bn}$ in mid-1985.

Broad Money: Broad money refers to money held as a form of savings as well as money held for transactions purposes. It provides a measure of the private sector's holdings of relatively liquid assets - i.e. those which could be converted with relative ease and without capital loss into spending on goods and services.

Bulldog Bonds: Bonds issued by overseas institutions and denominated in sterling.

Cash Ratio Deposits: These are non-interest bearing deposits which all institutions in the UK monetary sector must keep with the Bank. They are essentially a tax on the members of the monetary sector and are designed to provide income and resources for the Bank. They do not form any part of a system of monetary base control. The level is adjusted twice a year, normally on the third Monday after the April and October make-up days, and is at the rate of $1 / 2 \%$ of eligible liabilities.

Contingent Liability: A liability which is contingent on some other event. For example, a bank underwriting a bill will only have the liability to pay should the original drawer of the bill default.

Corset: See SSD.

Covered Interest Rate Differential: The differential between interest rates on instruments in different currencies after allowing for forward cover in the foreign exchange market. See Forward Exchange Market. 
Discount Houses (\& LDMA): The group of institutions whose traditional activity is the discounting of bills issued either by companies or the Treasury. The nine discount houses forming the London Discount Market Association (LDMA) are: Alexanders Discount; Cater Allen; Clive Discount; Gerrard and National; King and Shaxson; Quin Cope; Seccombe, Marshall and Campion; Smith St. Aubyn; and Union Discount.

Discount Window: The term used to describe the mechanism through which the Bank lends to the money market in order to relieve shortages of cash.

Disintermediation: The process whereby business which was previously intermediated by the banking system becomes channelled through other institutions. 'Cosmetic' disintermediation occurs if the bank still acts as an intermediary but the business does not appear on its balance sheet.

Domestic Credit Expansion: Domestic Credit Expansion is equivalent to the sum of the domestic counterparts to $E M 3$ growth plus bank lending in sterling to overseas.

Eligible Liabilities: The eligible liabilities of the UK monetary sector comprise basically their sterling sight and time deposits net of balances held with certain approved institutions. Specifically, eligible liabilities comprise: sight deposits (except those of overseas offices); time deposits, other than those of overseas offices, with an original maturity of two years or less; CDs issued; promissory notes, bills and other short term paper issued; items in suspense; $60 \%$ of credit items in the course of transmission; and net sterling liabilities to overseas offices (an overall net claim not being treated as an offset). From this total is subtracted the sum of: $60 \%$ of debit items in the course of collection; balances with the Bank (excluding special deposits and cash ratio deposits); secured and unsecured money with the LDMA; and secured money at call with money brokers and gilt edged jobbers.

Equity Withdrawal: A term normally used in relation to the housing market. It is said to occur if net new loans for house purchase exceed net private sector expenditure on housing.

Eurocurrency Deposits: Deposits with a bank that is not located in the country in whose currency the deposit is denominated. For example, dollars deposited in a London bank are called eurodollars; sterling deposited in a New York bank is called eurosterling. 
Forward Exchange Market: A market in which contracts are made to supply currencies at fixed dates in the future at fixed prices.

Funding: The term originally applied to the process of converting short term to long term debt. Government funding thus involved issuing longer dated instruments (e.g. gilt edged stocks) to replace Treasury bills. More recently the term has been used to refer to the total amount of government debt (both short and long term as well as National Savings) sold to the non-bank private sector.

Gilt edged stocks (Gilts): Stocks, issued by the government, normally paying a fixed amount of interest (in the form of a 'coupon') per year and having an original maturity of several years.

Intermediation: The process whereby funds are channelled, via an intermediary, from one sector of the economy to another. For example, banks may act as intermediaries between the personal sector (traditionally a net saver) and the company sector (traditionally a net borrower).

Liability Management: The process whereby banks adjust the volume of their deposits in order to accommodate changes in the demand for loans (the opposite process is termed asset management).

'Lifeboat': The term used to refer to the joint operation by the Bank and the clearing banks in 1973 to support the 'secondary' banks.

MO: MO is a measure of narrow money, and is alternatively termed the wide monetary base as it includes all the possible components of a monetary base measure. These are notes and coin held by the non-bank private sector, banks' holdings of cash (till money) and bankers' operational balances at the Bank of England. MO is currently the authorities' targetted measure of narrow money.

M1: A narrow measure of money comprising notes and coin in circulation with the public and the private sector's sterling sight deposits. Sterling sight deposits can be classified as either interest bearing or non-interest bearing. Adding just the non-interest bearing deposits to notes and coin gives the measure non-interest bearing $M 1$ (or nib M1).

M2: A specially devised measure of transactions balances which comprises non-interest bearing $M 1$, private sector interest bearing retail ster- 
ling bank deposits, private sector holdings of retail building society deposits and NSB ordinary accounts.

M3: M3, alternatively referred to as Total M3, is a measure of broad money. It adds to sterling M3 UK private sector foreign currency bank deposits.

Make-up Day: The day on which the banks make up their balance sheets for submission to the Bank. For the monthly banking statistics, make-up day is on the third Wednesday of each month (apart from December when it is the second Wednesday).

Monetary Base: The monetary base is defined as a subset of the monetary liabilities of the Bank of England. The three components which may be included are: (i) notes and coin in circulation with the public; (ii) notes and coin held by banks (as till money); and (iii) bankers' operational deposits at the Bank of England. MO, the wide measure of the monetary base, includes all three components.

Monetary Base Control: A method of monetary control which relies on the authorities influencing the level of monetary base.

Monetary Sector: The UK monetary sector comprises: (a) all recognised banks and LDTs; (b) the National Girobank; (c) the trustee savings banks; (d) the Banking Department of the Bank of England; and (e) those banks in the Channel Islands and the Isle of Man which have chosen to comply with the current monetary control arrangements. The monetary sector replaced the banking sector at the end of 1981. Broadly it differs from the banking sector in that it includes all recognised banks and LDTs (rather than just those on the statistical list), the trustee savings banks and the National Girobank.

Monetary Target: A target, normally expressed as a range (say, 5-9\%), for the growth of one or more measures of the money supply.

Narrow Money: Narrow money refers to money balances which are readily available to finance current spending, i.e. for 'transactions purposes'.

Off Balance Sheet Business: Banking business which is effectively carried out by a bank but which is not recorded on its balance sheet. For example, a bank may underwrite a bill which is then sold to the non-bank private 
sector. The bank is effectively acting as an intermediary but the business does not appear on its balance sheet.

Operational Deposits: These are deposits of the LCBs held at the Bank which are used for settling transactions between themselves and the Bank.

Original Maturity: The original maturity of an instrument is the term to maturity when the bill is issued.

Overfunding: The process whereby the Bank sells more government debt to the non-bank private sector than is needed to finance (or 'fund') the PSBR.

Private Sector Liquidity (PSL): Measures of private sector liquidity are normally distinguished from measures of money. They include selected liquid assets of the private sector whereas the monetary aggregates comprise selected components of the monetary sector's balance sheet (plus notes and coin in circulation with the public). The two most widely used PSL measures are PSL1 and PSL2.

PSL1: PSL1 is a measure of Private Sector Liquidity. It includes all the components of $E M 3$ (apart from private sector sterling time deposits with an original maturity of over two years) as well as private sector holdings of money market instruments (bank bills, Treasury bills, local authority deposits) and certificates of tax deposit.

PSL2: PSL2 adds to PSL1 private sector holdings of building society deposits (excluding term shares and SAYE) and National Savings instruments (excluding certificates, SAYE and other longer-term deposits) but, to avoid double-counting, excludes building society holdings of money market instruments and bank deposits.

Reserve Assets Ratio: Between September 1971 and August 1981, banks were required to keep a certain proportion of their eligible liabilities as reserve assets. The ratio was $12 \frac{1}{2} \%$ for the period up to January 1981 , when it was reduced to $10 \%$. It was temporarily reduced to $8 \%$ for most of March and April 1981 and abolished in August 1981. Reserve assets comprised:

i) Balances at the Bank (other than special deposits or supplementary special deposits)

ii) British Government and Northern Ireland Treasury bills 
iii) Secured money at call with the London discount market

iv) British government stocks with a residual maturity of less than one year

v) Local authority bills eligible for rediscount at the Bank

vi) Commercial bills eligible for rediscount at the Bank, up to a maximum of $2 \%$ of eligible liabilities.

Residual Maturity: The remaining term to maturity of an instrument. For example, a bill with an original maturity of three months issued two months ago has a residual maturity of one month.

Round-Tripping: The process whereby funds raised in one market are deposited in another to yield a profit. For example, a company may issue a bill and deposit the proceeds in the money market to yield a higher return (this process is also referred to as bill arbitrage).

Sale and Repurchase Agreement (REPO): An agreement whereby instruments are sold with an agreement to repurchase them at a specified future date.

Seasonal Adjustment: The process whereby recurrent variations in a series of data are removed.

Sight Deposits: Deposits which are withdrawable without notice. Sight deposits which are non-interest bearing consist predominantly of current (chequable) accounts. Sight deposits which are interest bearing include both current accounts and money market deposits which are withdrawable on demand.

Special Deposits: The authorities can call on the banks to place a certain percentage of their eligible liabilities in a special deposit at the Bank which is non-interest bearing. They have not been called since 1980. These deposits did not count as reserve assets when the reserve assets ratio was in place.

Spot Exchange Market: The market in which currencies are traded for immediate delivery, as opposed to the forward exchange market.

Sterling M3 ( $\mathrm{fM} 3$ ): $\mathrm{fM} 3$ is a measure of broad money. It comprises notes and coin held by the public plus all of the UK private sector's sterling deposits (both sight and time) held in UK banks. $\mathrm{fM} 3$ is currently the authorities' targetted measure of broad money. 
Supplementary Special Deposits (SSD): The Supplementary Special Deposit Scheme was a scheme which imposed penalties on the banking system for expanding their interest bearing eligible liabilities at a rate faster than that prescribed by the Bank of England. The scheme operated in three periods: December 1973 to February 1975; November 1976 to August 1977, and June 1978 to June 1980.

Tender: An offer to buy at a fixed price. For example, the discount houses at the weekly Treasury bill tender will offer to take up so many bills at a certain price.

Term Structure: The relationship between interest rates (and/or yields) at different maturities. For bonds, this is often expressed as a yield curve.

Till Money: The quantity of notes and coin held by banks. Alternatively termed vault cash.

Time Deposits: Deposits for which notice has to be given before they can be withdrawn without penalty.

Total M3: See M3.

Town Clearing: The town clearing facility enables a cheque for more than $£ 10,000$ drawn on an office of a London Clearing Bank located within a specified area of the City, to be presented by any such other office at the town clearing for settlement on the same day. The settlement takes place after the banks have closed for business.

Treasury Bills: Short term bills (normally three months maturity) issued by the government.

Vault Cash: See till money.

Wholesale deposits: Large deposits bearing an interest rate in line with market rates: for example, CDs.

Yield Curve: A curve showing the relationship between yields on bonds at different maturities. It is one of the most popular ways of expressing the term structure. 